\title{
The use of confocal laser scanning microscopy to analyze the process of parasitic protozoon-host cell interaction
}

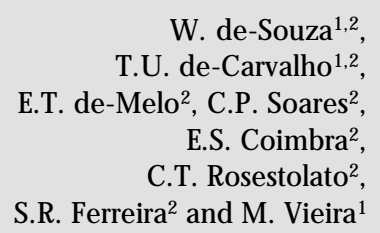

W. de-Souza1,2,

T.U. de-Carvalho ${ }^{1,2}$,

E.T. de-Melo², C.P. Soares',

E.S. Coimbra²,

C.T. Rosestolato2,

S.R. Ferreira ${ }^{2}$ and M. Vieira ${ }^{1}$

\author{
IInstituto de Biofísica Carlos Chagas Filho, U niversidade Federal do Rio de Janeiro, \\ Rio de Janeiro, RJ, Brasil \\ ${ }^{2}$ Centro de Biociências e Biotecnologia, Universidade Estadual do Norte Fluminense, \\ Campos dos Goytacazes, RJ, Brasil
}

\section{Correspondence \\ W. de-Souza \\ Instituto de Biofísica \\ UFRJ, CCS, Bloco G \\ 21941-590 Rio de Janeiro, RJ \\ Brasil \\ Fax: +55-21-260-2364 \\ E-mail:wsouza@ibccf.biof.ufrj.br}

\section{Presented at the International} Symposium: Biological Applications of Confocal Microscopy, Belo Horizonte, MG, Brasil, April 6-8, 1998.

Research supported by PRO NEX, FINEP, CNPq and FAPERJ.

Received May 14, 1998 Accepted July 20, 1998

\begin{abstract}
In this communication we review the results obtained with the confocal laser scanning microscope to characterize the interaction of epimastigote and trypomastigote forms of Trypanosoma cruzi and tachyzoites of Toxoplasma gondii with host cells. Early events of the interaction process were studied by the simultaneous localization of sites of protein phosphorylation, revealed by immunocytochemistry, and sites of actin assembly, revealed by the use of labeled phaloidin. The results obtained show that proteins localized in the interaction sites are phosphorylated. The process of formation of the parasitophorous vacuole was monitored by labeling the host cell surface with fluorescent probes for lipids (PKH26), proteins (DTAF) and sialic acid (FITC-thiosemicarbazide) before interaction with the parasites. Evidence was obtained indicating transfer of components of the host cell surface to the parasite surface in the beginning of the interaction process. We also analyzed the distribution of cytoskeletal structures (microtubules and microfilaments visualized with specific antibodies), mitochondria (visualized with rhodamine 123), the Golgi complex (visualized with C6-NBD-ceramide) and the endoplasmic reticulum (visualized with anti-reticulin antibodies and $\mathrm{DIOC}_{6}$ ) during the evolution of intracellular parasitism. The results obtained show that some, but not all, structures change their position during evolution of the intracellular parasitism.
\end{abstract}

\section{Introduction}

In recent years we have observed a significant increase in the number of publications dealing with the application of immunofluorescence microscopy in cell biology. This is mainly due to three basic reasons: a) the development of new reagents, which opened the possibility to label most of the cell structures and organelles with high specificity, even in living cells, b) the development of image processing techniques, allowing the superposition of images taken from the same field with different fluorochromes, as well as integration of images taken from various focal planes in one single plane, and c) the development of the confocal laser scanning microscope (CLSM), which permits the observation of very thin focal planes and their later processing as described in $b$. 
Several pathogenic protozoa exert their pathogenic effect due to their ability to attach to and penetrate different cell types, as is the case for Trypanosoma cruzi and Toxoplasma gondii (reviews in 1-3). The process of attachment requires recognition of surface components of the two cells involved in the interaction process, which then triggers the process of internalization. Although several parasite molecules involved in the recognition process have been isolated from the surface of $T$. cruzi, little information is available about $T$. gondii. Also, the role played by molecules exposed on the surface of host cells, as well as the basic phenomena related to the internalization process per se are unclear. Recent information indicates the participation of $\mathrm{Ca}^{2+}$ from both parasite and host cells in the early events related to the process of interaction (4-7). Independently of the mechanism used by the parasite to penetrate the cells there is the formation of a large vacuole, where the parasite is located immediately after penetration, known as the parasitophorous vacuole (PV). Available data indicate that the nature of the membrane lining the vacuole plays an important role in the fate of the parasite within the vacuole. For some parasites, such as $T$. gondii, a special PV which does not fuse with components of the endo-lysosomal pathway of the host cell is an ideal site for parasite replication (8-11). Other parasites, such as T. cruzi, must lyse the membrane lining the PV and enter into direct contact with the cytoplasmic structures of the host cell in order to start the process of division (12-14). Despite the importance of the PV, little information is available about the basic aspects related to its formation.

In this communication we will review the results obtained over the last years in our laboratory using confocal laser scanning immunofluorescence microscopy to analyze a) early events related to the process of $T$. cruzi- and $T$. gondii-host cell interaction, b) the formation of the PV, and c) the changes which take place in the distribution of cytoskeletal structures and organelles of the host cell during the evolution of intracellular parasitism.

\section{Early events of the protozoon-host cell interaction}

We have shown previously that drugs which inhibit protein kinases, especially tyrosine kinases, significantly block internalization of trypomastigote and epimastigote forms of T. cruzi $(15,16)$ and tachyzoites of T. gondii (17) into macrophages. In addition, it was also shown that depolymerization of actin filaments significantly inhibits parasite internalization (18). Based on these observations, we decided to use two approaches to analyze the early events during the process of interaction of $T$. cruzi and $T$. gondii with host cells, i.e., visualization of sites of protein phosphorylation and sites of actin polymerization. For these experiments we used tachyzoites from the virulent RH strain of $T$. gondii (maintained by intraperitoneal passages in CF1 mice and collected in phosphate-buffered saline (PBS), $\mathrm{pH} 7.2,48$ to $72 \mathrm{~h}$ after infection), epimastigote forms of T. cruzi grown axenically for $72 \mathrm{~h}$ at $28^{\circ} \mathrm{C}$ in LIT medium, and trypomastigote forms of the Y strain of T. cruzi obtained from the supernatant of heavily infected cells. As host cells we used mouse peritoneal resident macrophages and Vero cells in culture. One day before the experiments, the cells were placed on Linbro tissue plates containing a round sterile coverslip and maintained at $37^{\circ} \mathrm{C}$ overnight in $5 \% \mathrm{CO}_{2}$. Parasites and macrophages were allowed to interact for $30 \mathrm{~min}$ in 199 medium at $37^{\circ} \mathrm{C}$ in a $5 \% \mathrm{CO}_{2}$ atmosphere. After interaction, macrophages were washed three times with $1 \mathrm{mM}$ sodium ortho-vanadate in PHEM buffer (60 mM Pipes, $20 \mathrm{mM}$ HEPES, $10 \mathrm{mM}$ EGTA, $5 \mathrm{mM}$ magnesium chloride, $70 \mathrm{mM}$ potassium chloride, $\mathrm{pH}$ 7.2 ) and fixed with $4 \%$ freshly prepared formaldehyde in PHEM buffer, $\mathrm{pH}$ 7.2, first 
for $10 \mathrm{~min}$ at room temperature, and then for $50 \mathrm{~min}$ at $4^{\circ} \mathrm{C}$. When necessary cells were permeabilized with $0.1 \%$ Triton $\mathrm{X}-100$ in PHEM buffer for $90 \mathrm{~s}$, and then treated with a blocking solution containing $50 \mathrm{mM}$ ammonium chloride and 1.5\% BSA, in PHEM buffer, $\mathrm{pH} 7.2$, for $30 \mathrm{~min}$ at room temperature. The samples were incubated with phalloidin-rhodamine $(1: 100)$ diluted in a $1 \%$ BSA-PHEM solution, $\mathrm{pH} 7.2$, for $60 \mathrm{~min}$ at room temperature, washed three times with PHEM, pH 7.2, and first incubated for $2 \mathrm{~h}$ at room temperature with anti-phosphotyrosine (1:20) antibody diluted in 1\% BSA-PHEM, $\mathrm{pH}$ 7.2, supplemented with $2 \mathrm{mM}$ orthophosphoserine and $2 \mathrm{mM}$ ortho-phosphothreonine. Macrophages were then washed three times with PHEM buffer, $\mathrm{pH}$ 7.2, successively incubated with normal goat serum (1:100) for $30 \mathrm{~min}$, and FITC-labeled goat anti-mouse IgG $(1: 100)$ in 1\% BSA-PHEM solution, $\mathrm{pH} 7.2$, for $2 \mathrm{~h}$ at room temperature. Finally the coverslips were washed and mounted onto slides with fluorescence mounting medium (Vectashield or N-propyl-gallate) and observed with an Axiovert 410 Zeiss confocal laser scanning microscope, using a 488 (LP 415 filter) or 543 (LP 570 filter) argon laser (Carl Zeiss, Oberkochen, Germany).

Our observations showed a concentration of phosphotyrosine residues at the contact region of macrophages with epimastigotes and trypomastigotes (Figure 1). Intense phalloidin staining was also observed in the same region. Overlays of the two fluorescent labelings clearly showed the colocalization of phosphotyrosine proteins and points of concentration of macrophage actin microfilaments. In the case of $T$. gondii there was no correlation between protein phosphorylation and actin polymerization (Figure 2). However, phosphotyrosine residues were seen throughout the surface of cells allowed to interact with the parasites, even in cells which did not present attached or internalized parasites.

\section{Formation of the parasitophorous vacuole}

In order to analyze the process of formation of the parasitophorous vacuole we decided first to label the surface of the host cells with fluorescent probes and then incubate them in the presence of the parasites, and follow the fate of the probes. We used probes for lipids (19), proteins (20) and sialic acid (21).

Lipids were labeled with PKH26. The cells were washed three times in glucose isotonic solution (5.4\%) and incubated with PKH26 $(100 \mu \mathrm{g} / \mathrm{ml})$ in an isotonic glucose solution for $30 \mathrm{~s}$ at $4^{\circ} \mathrm{C}$. Then, $500 \mu \mathrm{l}$ of fetal
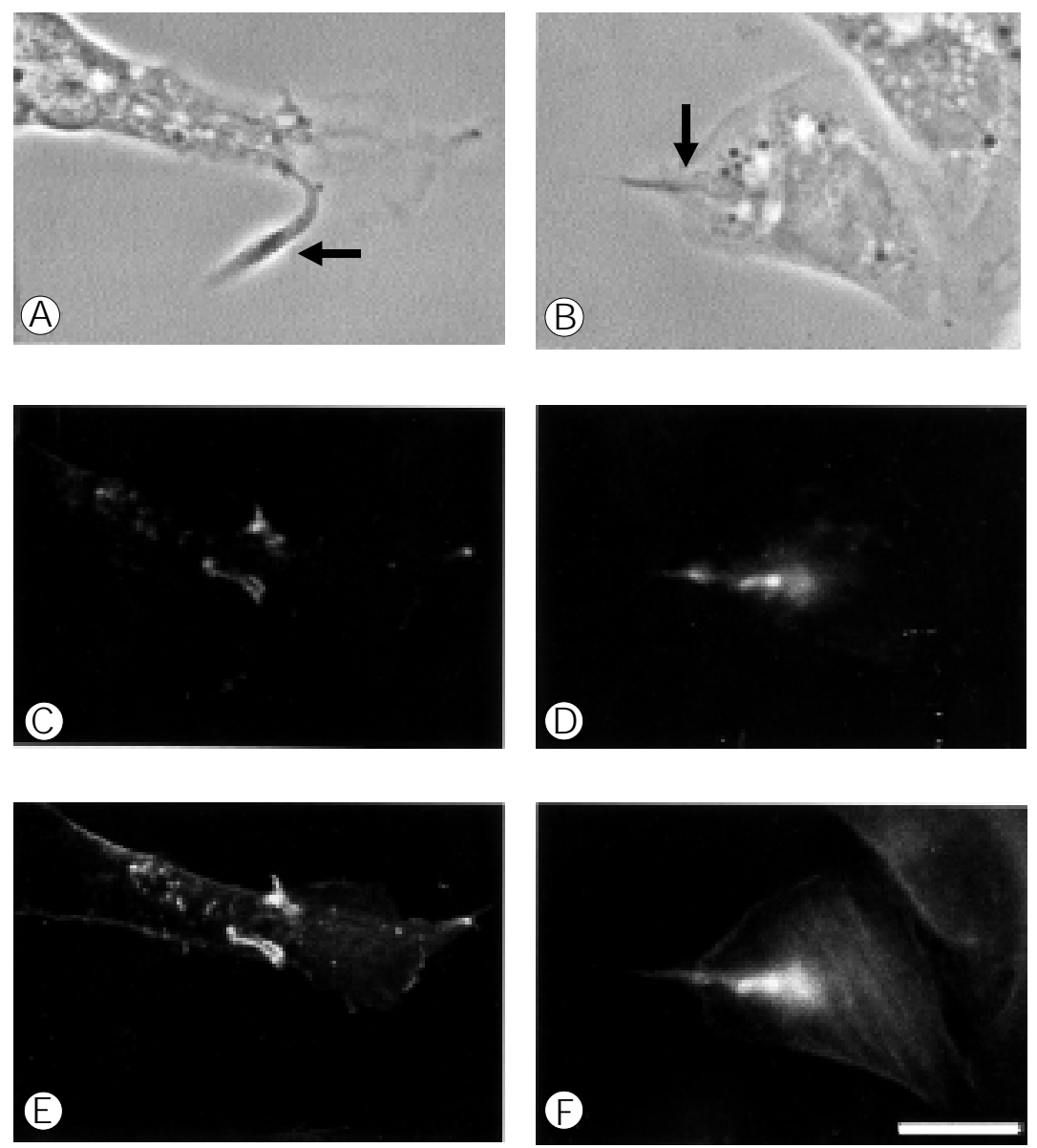

Figure 1 - Parasites allowed to interact with macrophages (arrows). A and B show images by phase contrast microscopy. Visualization of sites of tyrosine phosphorylation (C,D) and actin microfilaments $(E, F)$ in macrophages allowed to interact with trypomastigote forms of Trypanosoma cruzi. Bar $=50 \mu \mathrm{m}$. 
Figure 2 - Parasites allowed to interact with macrophages. A shows an image by phase contrast microscopy. Visualization of sites of tyrosine phosphorylation (B) and actin microfilaments (C) in macrophages allowed to interact with tachyzoites of Toxoplasma gondii. Bar $=10 \mu \mathrm{m}$. calf serum (FCS) was added and the cells were washed twice with isotonic glucose solution. The parasites were then incubated with labeled cells (50:1 parasite-host cell ratio) for 15 and $30 \mathrm{~s}, 1$ and $24 \mathrm{~h}$ at $37^{\circ} \mathrm{C}$ in a $5 \% \mathrm{CO}_{2}$ atmosphere. The cells were washed twice with PBS to remove extracellular para-

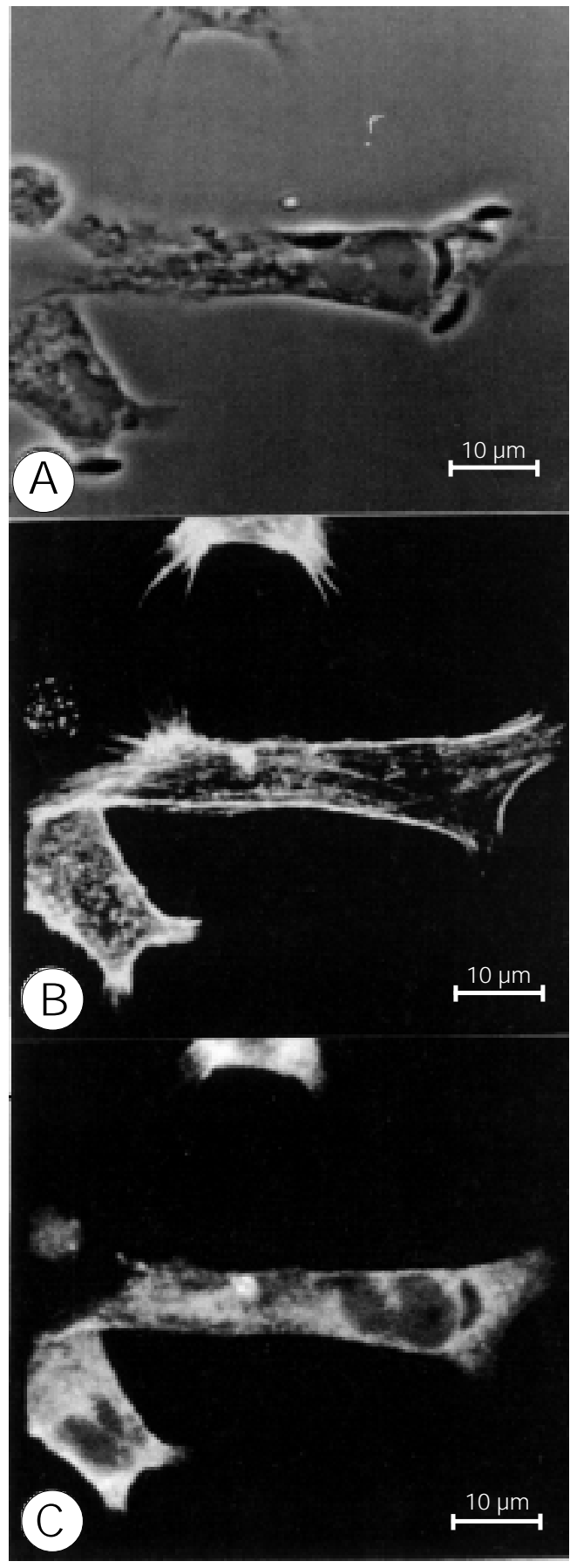

sites and fixed in $4 \%$ freshly prepared formaldehyde solution in $0.1 \mathrm{M}$ phosphate buffer, $\mathrm{pH}$ 7.2, mounted and observed with a CLSM. Noninfected cells labeled only with PKH26 for $30 \mathrm{~min}$ at $4^{\circ} \mathrm{C}$ were used as control. The observation of untreated cells incubated with PKH26 at low temperature and then fixed showed labeling of the cell surface. After short periods of incubation with $T$. gondii, the cultures showed intense labeling of areas where parasites attached to the host cell surface and recently internalized parasites were observed (Figure 3A,B). After 15 and 30 min of interaction the PV membrane (PVM) presented light staining and an intensely labeled intravacuolar parasite, mainly in the posterior portion. The host cell perinuclear region was also labeled. Labeling of the PVM and of the intravacuolar parasites was observed after $60 \mathrm{~min}$ and $24 \mathrm{~h}$ of interaction (Figure 3C,D). In the case of $T$. cruzi we observed labeling of the membrane lining the parasitophorous vacuole (see Figure 5).

For protein labeling we used DTAF. The cells were washed once with PBS, $\mathrm{pH}$ 7.2, and with $\mathrm{PBS} / 200 \mathrm{mM}$ borate, $\mathrm{pH} 8.5$, at a 1:1 proportion. The cells were incubated with DTAF in the dark for $15 \mathrm{~min}$ at $4^{\circ} \mathrm{C}$. Then, they were washed once in PBS $+20 \%$ FCS and incubated in PBS $+20 \%$ FCS for 5 min at $4^{\circ} \mathrm{C}$, washed in PBS once and incubated in 199 medium. Subsequently the parasites were incubated with labeled cells (50:1 parasite-host cell ratio) for 15 and $30 \mathrm{~s}$, and 1 and $24 \mathrm{~h}$ at $37^{\circ} \mathrm{C}$ in a $5 \% \mathrm{CO}_{2}$ atmosphere. The cells were then washed twice with PBS to remove extracellular parasites and processed for microscopy as described above. Control cells labeled with DTAF for $30 \mathrm{~min}$ at $4^{\circ} \mathrm{C}$ showed labeling of the whole cell surface. After interaction with $T$. gondii for different periods of time, images of tachyzoites attached to, as well as internalized by the cells were observed. In those attached to the cell surface, labeling of the host cell surface and of the parasite surface was clearly 
visible (Figure 4A,B). After 30 min of interaction tachyzoites were seen within recently formed PV. Labeling of the PVM and of intravacuolar tachyzoites was noticed. After prolonged incubation times (60 min and 24 h) no labeling of the PVM or intravacuolar tachyzoites was observed. However, labeled structures dispersed throughout the host cell cytoplasm were observed (Figure 4C,D). In the case of $T$. cruzi we also observed labeling of the areas of interaction and of the parasitophorous vacuole (Figure 5).

For labeling of sialic acid-containing glycoconjugates we used fluorescein-5-thiosemicarbazide. The cells were washed in PBS twice, and incubated in a freshly prepared sodium m-periodate solution $(5 \mathrm{mM}$ in PBS) at a concentration of $0.5 \mathrm{mM}$ for 30 $\min$ at $4^{\circ} \mathrm{C}$. The cells were then washed three times with PBS at $4{ }^{\circ} \mathrm{C}$ and incubated in PBS containing $0.66 \mathrm{mg} / \mathrm{ml}$ fluorescein-5-thiosemicarbazide for $30 \mathrm{~min}$ at $4^{\circ} \mathrm{C}$, washed in 199 medium twice and incubated with parasites (50:1 parasite-host cell ratio) for 15 and $30 \mathrm{~s}$ and 1 and $24 \mathrm{~h}$ at $37^{\circ} \mathrm{C}$ in a $5 \% \mathrm{CO}_{2}$ atmosphere. The cells were then washed twice with PBS to remove extracellular parasites and processed for microscopy as described above. Control cells showed a punctate labeling of the cell surface. Following incubation with the tachyzoites, intense labeling of the parasites attached to the host cell surface was observed. After internalization no labeling of the PVM or the intravacuolar parasites was seen. However, labeling of cytoplasmic structures of the host cell was observed. In the case of T. cruzi we observed labeling of the region of interaction and of the membrane lining the parasitophorous vacuole (Figure 6).

In the case of $T$. gondii, in some experiments the parasites were first labeled in suspension with PKH26, DTAF and fluorescein thiosemicarbazide for $5 \mathrm{~min}$ at $4^{\circ} \mathrm{C}$ in the dark, washed as described previously, and incubated with Vero cells for 15, 30 and 60 $\min$ at $37^{\circ} \mathrm{C}$ in a $5 \% \mathrm{CO}_{2}$ atmosphere. The cells were then washed twice with PBS to remove extracellular parasites and processed for microscopy as described above. Labeling was observed only at the sites of contact of the parasites with the host cell. No labeling of intracellular parasites or of structures of the host cell was observed. It is important to point out that the parasites were viable and infected the cells.

One of the most enigmatic issues surrounding parasite invasion is the origin and composition of the PVM. The ability of the parasitophorous vacuole containing $T$. gondii to resist endocytic fusion and processing may be due to its unique composition. In general, endocytic vacuoles are formed by one of three processes: a) receptor-mediated endocytosis, involving clustering of ligandreceptor complexes in chlatrin-coated pits $(22)$; b) pinocytosis of fluid into small vesicles and macropinocytosis in association with extensive membrane ruffling that is stimulated by growth hormones (23); c) phagocy-

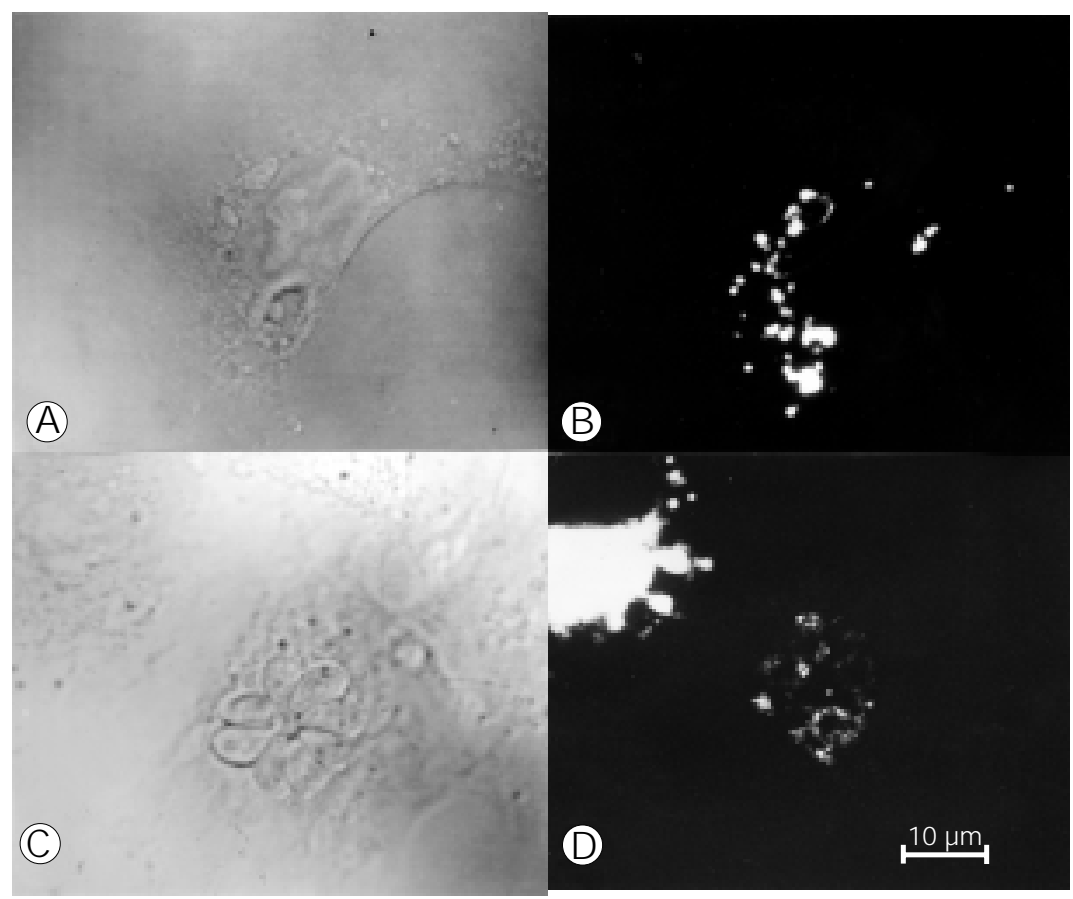

Figure 3 - Labeling of Vero cells with PKH26 and observation by differential interference microscopy $(A, C)$ and CLSM (B,D). At early infection times $(1 \mathrm{~h})$ labeling of tachyzoites of Toxoplasma gondii attached to the host cell surface or recently internalized is evident $(B)$. After prolonged incubation times $(24 \mathrm{~h}$ ) the parasites are still labeled (D). Bar $=10 \mu \mathrm{m}$. 


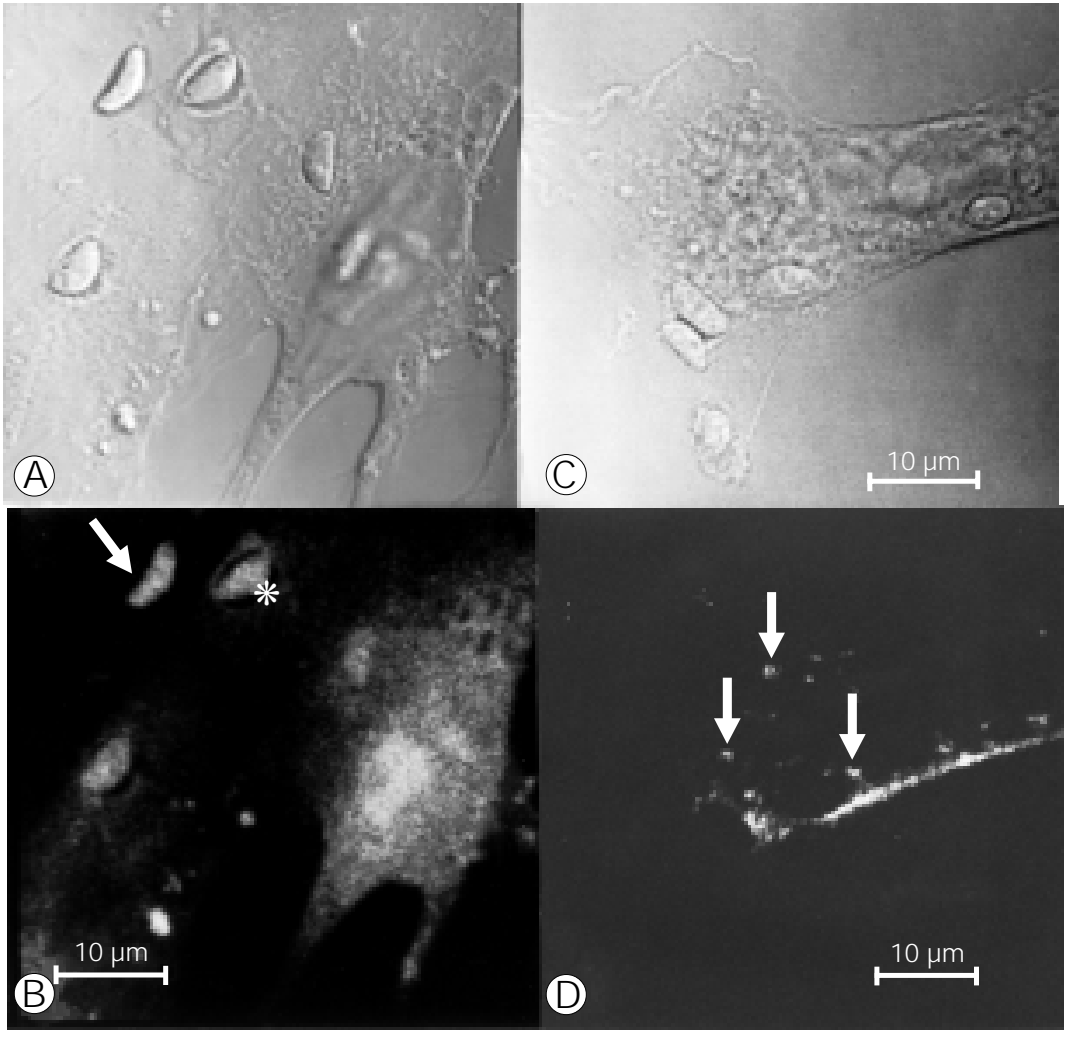

Figure 4 - Labeling of the Vero cell surface with DTAF and observation by differential interference microscopy $(A, C)$ and CLSM (B,D). At early infection times (15 min) labeling is observed at sites of tachyzoite attachment (arrow in B), and in intravacuolar parasites (asterisk in B). After prolonged incubation times (24 h) no labeling of the parasites is observed. However, some cytoplasmic structures are labeled (arrows in D). Bar $=10 \mu \mathrm{m}$.

tosis, through the action of multivalent receptors, and organization of the cytoskeleton (24). In some situations $T$. gondii invasion involves a phagocytic activity by the host cell (25). In most cases, however, invasion does not appear to be similar to any of the three processes cited above. Two models have been proposed to explain the formation of the PVM: a) the vacuole may be formed by simple invagination of the plasma membrane or b) formation of the PVM is based on parasite secretion of pre-formed lipid stores that assemble to form the vacuole membrane. This specialized PV membrane, which lacks plasma membrane markers from the host cell, is thought to account for the irreversible fusion incompetence of the parasitophorous vacuole, presumably because it lacks any signals for fusion with other com- partments. Specific plasma membrane proteins have been shown to be reduced or absent from newly formed phagosomes during engulfment of $L$. pneumophila (26), $T$. cruzi $(27,28)$, L. mexicana $(29,30)$ and $T$. gondii (31). These parasites have different intracellular fates, indicating that exclusion or removal of plasma membrane proteins might interfere with the behavior of the vacuole.

The fluorescent lipophilic probe PKH26, that binds irreversibly within cell membranes (19), was used to label the host cell membrane and to follow the fate of lipids during the PV formation in cells allowed to interact with $T$. gondii and $T$. cruzi. Our observations clearly show that during the internalization process labeled portions of the host cell plasma membrane are internalized and will be part of the PVM. In addition, later on the intravacuolar tachyzoites are intensely labeled indicating transfer of lipid from the PVM to the vacuole and to the parasite. Previous studies have shown that intravacuolar tachyzoites release macromolecules located within the dense granules, which remain in the vacuole (32) and are also incorporated into the intravacuolar membranous network and the PVM $(33,34)$. With the evolution of intravacuolar parasitism the intensity of labeling decreases, possibly due to dilution of the label among the new parasites formed after division (35). Observation of malaria invasion in red blood cells labeled with fluorescent lipids clearly showed that the vacuole originated by invagination of the red cell membrane (21). Joiner (36) and Sinai and Joiner (37) suggested that insertion of parasite lipids into the PVM might affect PVM interaction with other cell membranes, preventing fusion with endocytic compartments. Suss-Toby (38) reported that a small amount of parasite-derived material $(0-18.5 \%$ of the total surface area of the PVM) may be inserted into the host cell plasma membrane. Our observations cannot definitively rule out bulk insertion of lipids 
as another possible mechanism of PVM formation, as previously suggested (36).

We used DTAF, which reacts both with primary and secondary amine groups (20), to label membrane proteins of the macrophages before interaction with parasites in order to follow the fate of the labeled proteins during the parasite-host cell interaction process. As expected, only the macrophage surface was labeled when incubation was carried out at $4^{\circ} \mathrm{C}$. However, when these labeled cells were incubated in the presence of parasites at $37^{\circ} \mathrm{C}$ labeling of the surface of attached parasites was evident. This is an interesting observation which suggests a process of transfer of components of the host cell surface to the tachyzoite surface during the early steps of the interaction process. Previous studies have shown that, after parasite attachment, secretion of microneme components followed by secretion of rhoptry components occurs (32) and it has been suggested that these secretory molecules play some role in the process of host cell invasion by the protozoan. Our observations suggest that components of the host cell may also be transferred to the parasite, indicating the complexity of the interaction process. Once the parasites were internalized, labeling of the PVM and of the intravacuolar parasites was evident, indicating that at least some plasma membrane components of the host cell are internalized and will become part of the PVM. Previous studies using freeze-fracture have shown that the PVM of $T$. gondiicontaining PV presents a lower density of intramembranous particles as compared with the host cell plasma membrane (39). These observations are also in agreement with cytochemical studies showing the absence of plasma membrane enzymes in the membrane lining the vacuole (30).

Our observations using host cells previously labeled with fluorescein-thiosemicarbazide showed intense labeling of the surface of parasites attached to the cell surface, suggesting transfer of labeled molecules from

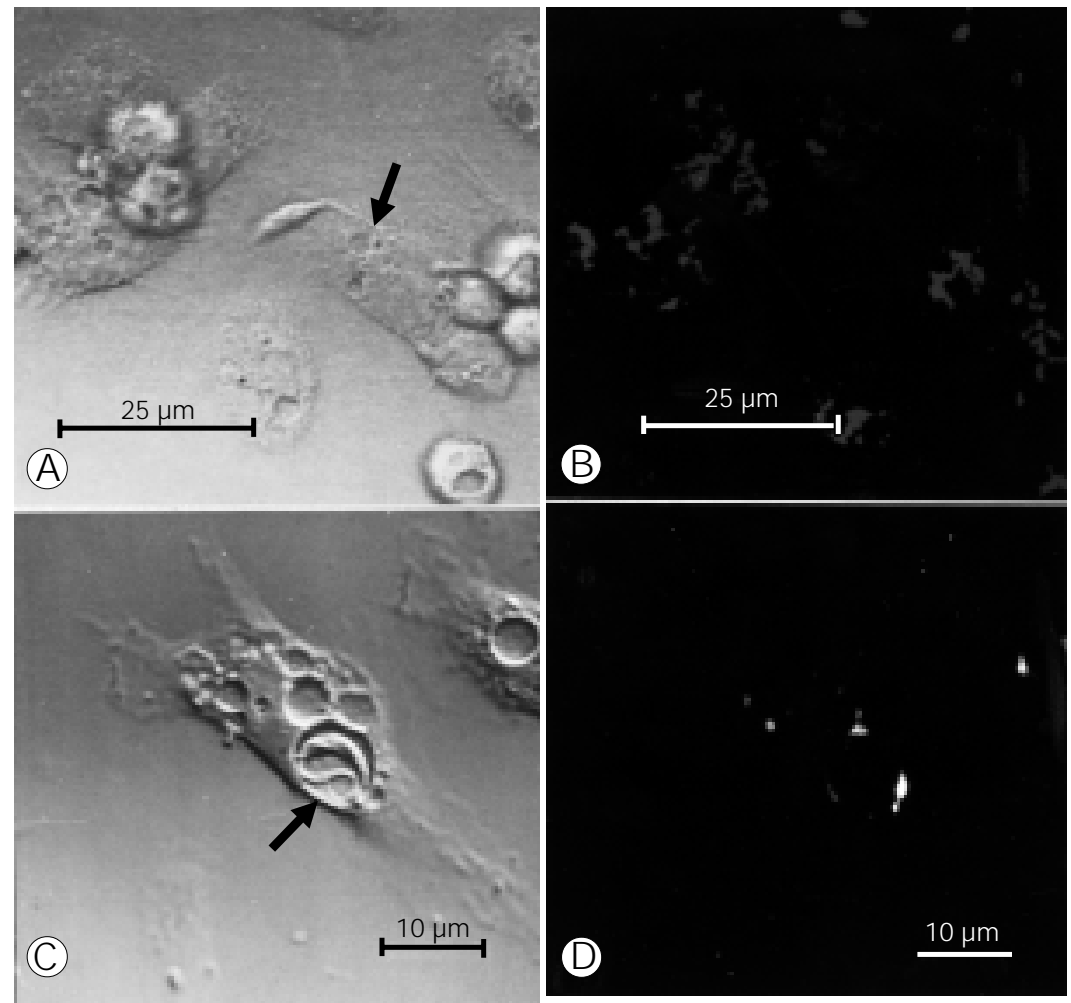

Figure 5 - Labeling of the cell with DTAF and observation by differential interference microscopy $(A, C)$ and CLSM $(B, D)$ following interaction with epimastigote $(A, B)$ and trypomastigote $(C, D)$ forms of Trypanosoma cruzi. In the case of attached epimastigotes, labeling of the attachment region is observed (arrow in A). Labeling of the vacuole containing internalized trypomastigotes was observed (arrow in C). A,B: Bar $=25 \mu \mathrm{m} ; \mathrm{C}, \mathrm{D}: \mathrm{Bar}=10$ $\mu \mathrm{m}$.

the host cell to the parasite surface. However, in contrast to what was observed with the labels for proteins and lipids, no labeling of the PVM or intravacuolar parasites was observed. This observation suggests that sialoglycoconjugates exposed on the host cell surface are not internalized during the process of internalization of $T$. gondii tachyzoites, being excluded in a not yet defined step of the process. This result was unexpected in view of previous studies showing that surface anionic sites of macrophages, detected using cationized ferritin particles, were internalized together with untreated tachyzoites and excluded when antibody-coated parasites were used (40). The observation that attached, but not internalized, parasites were labeled also suggests removal of surface components of the para- 
site during the internalization process. However, labeled cytoplasmic structures were seen in the host cell. They probably correspond to organelles of the endocytic pathway formed by invagination of other regions of the host cell surface not involved in interaction with the parasites.

We observed that incubation of tachyzoites in the presence of PKH26, DTAF and, to a lesser extent, FITC-thiosemicarbazide labeled their surface. When labeled parasites were allowed to interact with host cells intense labeling of the areas of contact between the parasite and the host cell was observed. However, neither the PVM nor the intravacuolar parasites were labeled, indicating that the surface molecules were released into the extracellular medium before the internalization process. Previous studies

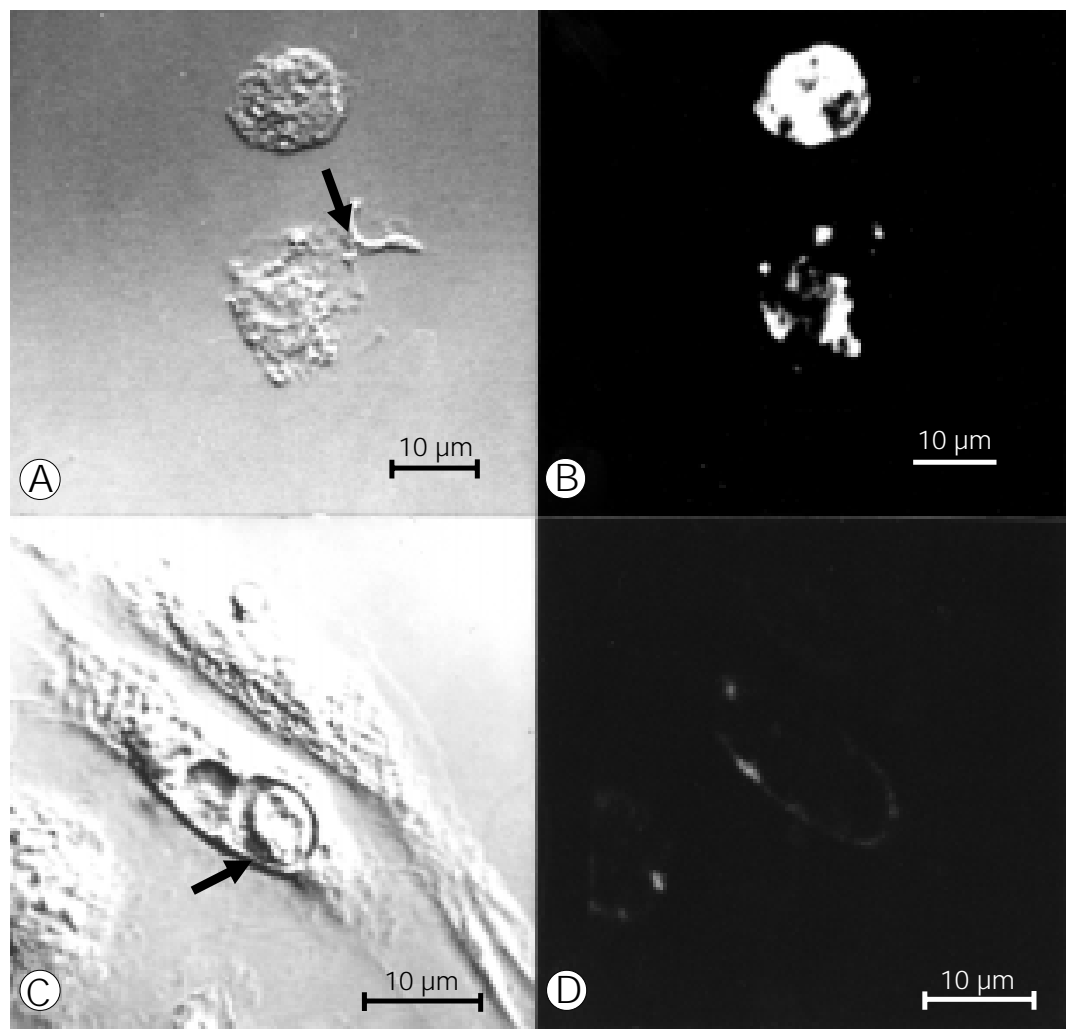

Figure 6 - Labeling of the cell with FITC-thiosemicarbazide and observation by differential interference microscopy $(A, C)$ and CLSM $(B, D)$ following interaction with the trypomastigote form of Trypanosoma cruzi. Labeling of the region of adhesion (arrow in $A$ ) and within the vacuole (arrow in C) is observed. Bar $=10 \mu \mathrm{m}$. have shown that malaria merozoites labeled with fluorescent fatty acids transfer fluorescent material to the parasitophorous vacuole during invasion (41). Specific proteins $(42,43)$ and lipids $(41)$ are thought to be transferred from the apical organelles during invagination, contributing to the formation of the PVM.

Taken together, the available data suggest that, after the initial contact of $T$. gondii tachyzoites with the surface of the host cell, interchange of surface components of the two interacting cells takes place. This phenomenon, in association with the release of macromolecules found in the micronemes and rhoptries and the invagination of the host cell plasma membrane, originates the initial parasitophorous vacuole membrane which surrounds the parasite-containing vacuole.

In the case of $T$. cruzi our observations suggest that a significant portion of the components found in the plasma membrane of the host cell is internalized during parasite penetration and becomes part of the parasitophorous vacuole. It is important to point out, however, that in the case of T. cruzi this membrane has a short life span since it is completely lysed a few hours after its formation (12-14).

\section{Re-distribution of cytoplasmic structures}

We analyzed the distribution of microtubules, microfilaments, endoplasmic reticulum, Golgi complex, and mitochondria of the host cell during the process of interaction of $T$. cruzi and $T$. gondii with host cells. In all cases the parasites were allowed to interact with the host cells as described above for periods varying from a few minutes to $72 \mathrm{~h}$. The interaction was interrupted by fixation in a solution containing $4 \%$ freshly prepared formaldehyde.

To visualize microtubules we used a mouse monoclonal anti- $\alpha$-tubulin antiboby 
diluted at 1:50 in PHEM buffer, $\mathrm{pH}$ 6.8. An FITC-conjugated secondary goat anti-mouse IgG was used at 1:50 dilution in PHEM buffer to visualize the first antibody. Control and infected cells grown in $13-\mathrm{mm}$ round coverslips were fixed in a solution containing $0.1 \%$ glutaraldehyde, $3.7 \%$ formaldehyde and $0.3 \%$ Triton X-100 in PHEM for 3 min, washed in PHEM (two times), incubated with $50 \mathrm{mM}$ ammonium chloride to block free aldehyde groups, washed again in PHEM-1\% BSA and incubated in the presence of anti- $\alpha$-tubulin antibody for $1 \mathrm{~h}$ at room temperature. Subsequently the cells were washed and incubated with FITC-labeled secondary antibody, diluted 1:50, for 1 $\mathrm{h}$ at room temperature in the dark. The same coverslips were incubated for $1 \mathrm{~h}$ at room temperature with phalloidin rhodamine at $1 /$ 100 dilution to visualize actin filaments. The coverslips were mounted in N-propyl-gallate and observed with a CLSM.

Actin filaments were organized as stress fibers distributed throughout the cytoplasm. We observed two labeling patterns for actin filaments in cells allowed to interact with $T$. cruzi. First, a concentration of actin filaments around the portion of the parasite in close association with the host cell (Figure 7). Second, some partially internalized parasites showed no concentration of actin filaments around them. Both types of images could be observed in the same cell, suggesting that both an active penetration process and typical phagocytosis can be used by the parasite to penetrate host cells. Noninfected cells showed microtubules irradiating from the microtubule organizing center (MTOC) to the cell periphery, as also described by others (Figure 8A). One process predominates over the other according to cell type. The organization of microtubules showed no change during the first hour of infection. After $24 \mathrm{~h}$ of infection, we observed a possible association between amastigote forms and microtubules (Figure 8B) but no changes in the pattern of microfilament distribution.

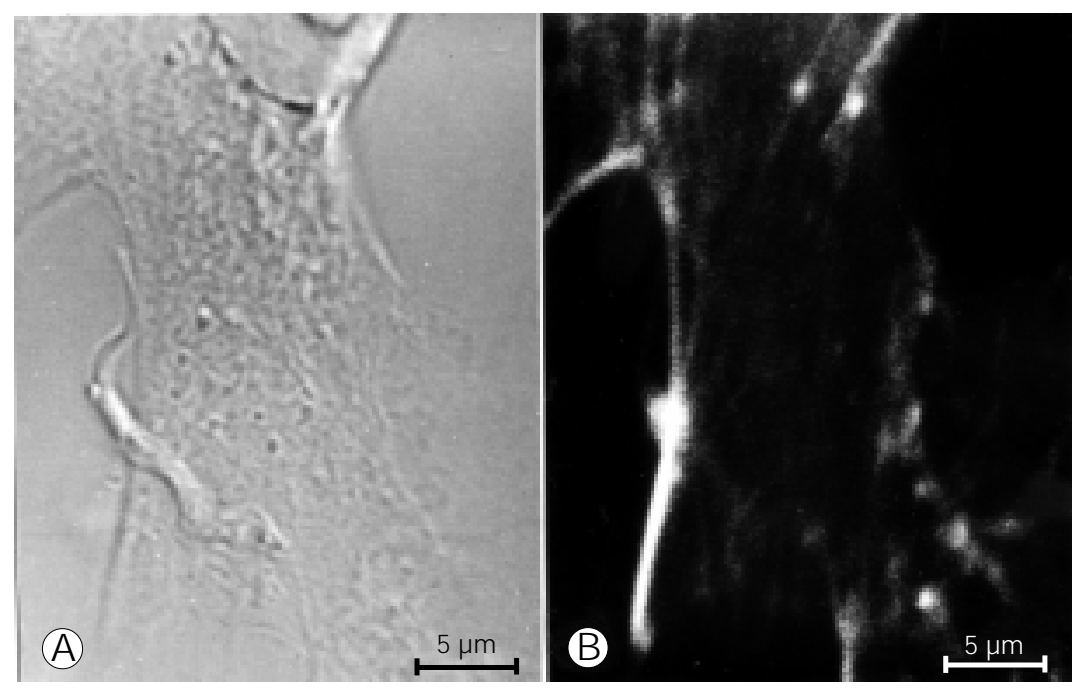

Figure 7 - Concentration of actin microfilaments observed at the point of initial contact of a trypomastigote form of Trypanosoma cruzi with the host cell. Bar $=5 \mu \mathrm{m}$. A, Interference contrast microscopy; B, CLSM.

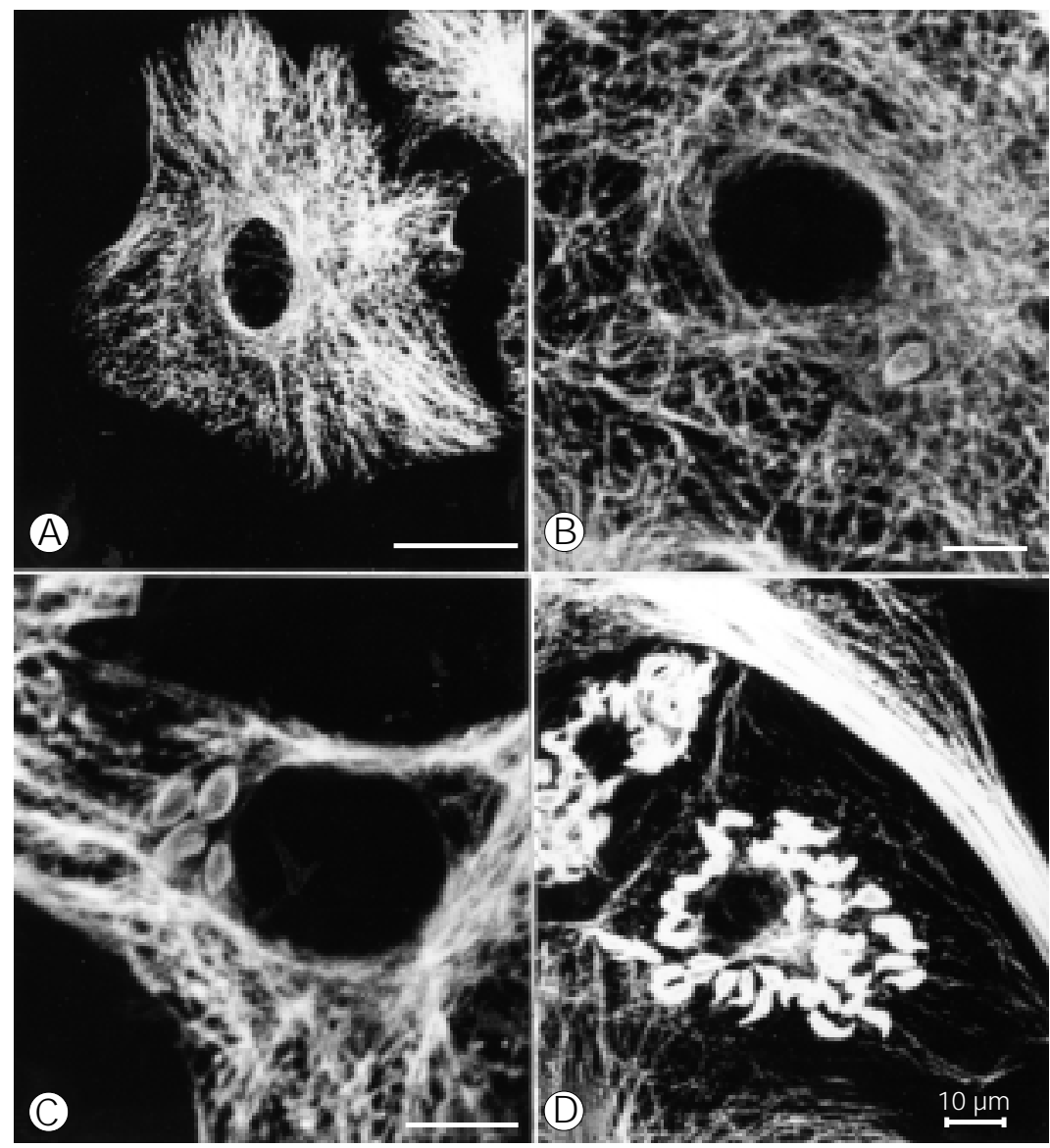

Figure 8 - Distribution of microtubules visualized with anti-tubulin antibodies, in control cells (A) and cells infected with Trypanosoma cruzi after 24 (B), 48 (C) and 72 (D) h. A: Bar $=25$ $\mu \mathrm{m}$; B-D: Bar $=10 \mu \mathrm{m}$. 


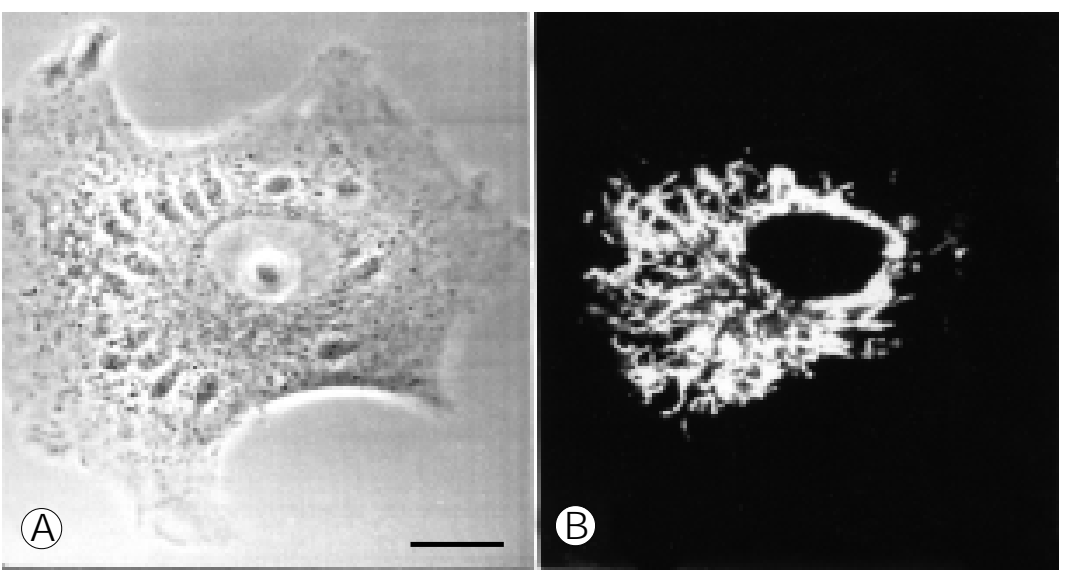

Figure 9 - Localization of mitochondria, using rhodamine 123, in cells infected with Trypanosoma cruzi for $48 \mathrm{~h}$. Bar $=25 \mu \mathrm{m}$. A, Interference contrast microscopy; B, CLSM.

Figure 10 - Localization of the endoplasmic reticulum, using anti-calreticulin antibodies, in cells infected with Toxoplasma gondii. A, Interference microscopy; B, CLSM. Labeling of the perivacuolar region and of the intravacuolar tachyzoites is observed. Bar $=2.2 \mu \mathrm{m}$.
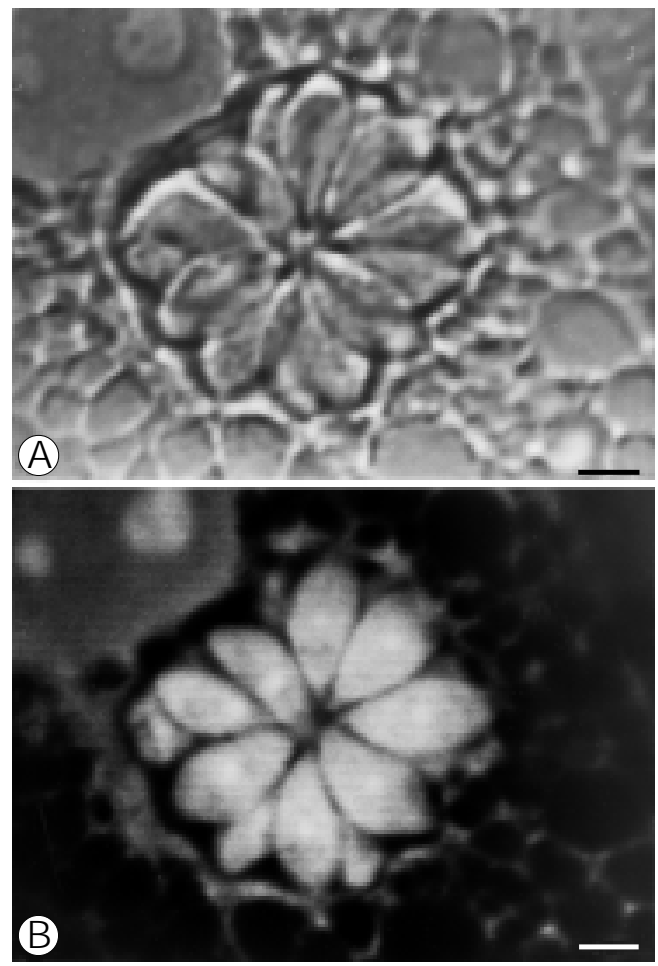

Amastigote forms were always observed in the perinuclear region, although they could also be observed in other regions of the cytoplasm. At $48 \mathrm{~h}$ of infection the organization of microtubules and microfilaments was still preserved, even near the parasites (Figure $8 \mathrm{C}$ ). After $72 \mathrm{~h}$, we noticed a reduction and/or a redistribution of the microtubular lattice in response to infection by T. cruzi. At this time there was a large number of amastigote forms, and we could observe cells full of trypomastigote forms as well as areas of close contact between amastigotes and microtubules (Figure 8D). The actin filaments at this time showed reorganization to the periphery of the cell, although in some cells, they were still located near the parasites.

In most of the cells infected with $T$. gondii we did not observe concentration of actin filaments in the region of interaction. Following internalization, no significant changes occurred in the distribution of actin filaments. In contrast, there was a concentration of microtubules forming layers around the parasitophorous vacuole, as confirmed by transmission electron microscopy.

For visualization of mitochondria the laser dye rhodamine 123 (44) was dissolved in dimethylsulfoxide at a concentration of 1 $\mathrm{mg} / \mathrm{ml}$ and subsequently diluted to $10 \mu \mathrm{g} / \mathrm{ml}$ in 199 medium. Noninfected and infected cells cultured on 13-mm diameter glass coverslips were incubated with rhodamine 123 for $30 \mathrm{~min}$ at $37^{\circ} \mathrm{C}$. The cells were then rinsed three to five times with 199 medium, mounted and observed with a CLSM. In $T$. cruzi-infected cells the mitochondria were randomly distributed (Figure 9). In the case of $T$. gondii, however, there was a clear concentration of the host cell mitochondria around the parasitophorous vacuole (45).

For visualization of the Golgi complex, cells were incubated in a solution containing $1.4 \mu \mathrm{M}$ of C6-NBD-ceramide plus bovine serum albumin (46) diluted in 199 medium without serum for $10 \mathrm{~min}$ at $37^{\circ} \mathrm{C}$. The cells were then washed three times with 199 medium without serum and incubated in the same medium for $30 \mathrm{~min}$ at $37^{\circ} \mathrm{C}$. The cultures were then washed twice in 199 medium, mounted and observed as described above. In no cases did we observe a redistribution of the Golgi complex, which was always concentrated around the host cell nucleus (47).

For visualization of the endoplasmic 
reticulum (ER), permeabilized cells were incubated in the presence of polyclonal antibodies recognizing calreticulin and developed as described above. We also used the dye $\mathrm{DIOC}_{6}(48)$ to label the ER. The results obtained with $T$. gondii-infected cells showed a clear association of the ER with the membrane lining the parasitophorous vacuole. Labeling of the intravacuolar parasites was also observed (Figure 10). This observation was confirmed by electron microscopy (49).

\section{References}

1. Sibley LD (1995). Invasion of vertebrate cells by Toxoplasma gondii. Trends in Cell Biology, 5: 129-132.

2. Burleigh BA \& Andrews NW (1995). The mechanism of Trypanosoma cruzi invasion of mammalian cells. Annual Review of Microbiology, 49: 175-200.

3. Araujo-J orge TC (1989). The biology of Trypanosoma cruzi-macrophage interaction. Memórias do Instituto Oswaldo Cruz, 84: 441-462.

4. Moreno SNJ, Silva J, Vercesi AE \& Docampo R (1994). Cytosolic-free calcium elevation in Trypanosoma cruzi is required for cell invasion. J ournal of Experimental Medicine, 180: 1535-1540.

5. Yakubu MA, M ajunder S \& Kierszembaum F (1994). Changes in Trypanosoma cruzi infectivity by treatments that affect calcium ion levels. Molecular and Biochemical Parasitology, 66: 119-125.

6. Dorta ML, Ferreira AT, Oshiro MEM \& Yoshida N (1995). $\mathrm{Ca}^{2+}$ signal induced by Trypanosoma cruzi metacyclic trypomastigotes surface molecules implicated in mammalian cell invasion. Molecular and Biochemical Parasitology, 73: 285-296.

7. Pezzela N, Bouchot A, Bonhomme A, Pingret Z, Klein C, Burlet $H$, Balossier $G$, Bonhomme P \& Pinan J M (1997). Involvement of calcium and calmodulin in Toxoplasma gondii tachyzoite invasion. European J ournal of Cell Biology, 74: 92-101.

8. J ones TC \& Hirsh J G (1972). The interaction of Toxoplasma gondii and mammalian cells. II. The absence of lysosomal fusion with phagocytic vacuoles containing living parasites. J ournal of Experimental Medicine, 136: 1173-1194.

9. Sibley LD, Weidner E \& Krahenbuhl J L (1985). Phagosome acidification blocked by intracellular Toxoplasma gondii. Nature, 315: 416-419.

10. Meirelles MNL \& De Souza W (1983). Interaction of lysosomes with endocytic vacuoles in macrophages simultaneously infected with Trypanosoma cruzi and Toxoplasma gondii. J ournal of Submicroscopic Cytology, 15: 889-896.
11. J oiner KA, Fulhman SA, Miettinen HM, Kasper LH \& Mellman I (1990). Toxoplasma gondii: fusion, competence of parasitophorous vacuoles in Fc receptortransfected fibroblasts. Science, 249: 641646.

12. Nogueira N \& Cohn Z (1976). Trypanosoma cruzi: mechanism of entry and intracellular fate in mammalian cells. J ournal of Experimental Medicine, 143: 14021420.

13. Carvalho TMU \& De Souza W (1989). Early events related with behaviour of Trypanosoma cruzi in the endocytic vacuole in mouse peritoneal macrophages. Cell Structure and Function, 14: 383-392.

14. Ley $\vee$, Robbins ES, Nussenzweig $\vee \&$ Andrews N (1988). The exit of Trypanosoma cruzi from the phagosome is inhibited by raising the $\mathrm{pH}$ of acidic compartments. J ournal of Experimental Medicine, 171: 401-413.

15. Vieira M, De Carvalho TU \& De Souza W (1994). Effect of protein kinase inhibitors on the invasion process of macrophages by Trypanosoma cruzi. Biochemical and Biophysical Research Communications, 15: 967-971.

16. Vieira M, Dutra , De Carvalho TU, Cunha e Silva N, Souto-Padron T \& De Souza W (1998). Tyrosine phosphorylation, PI 3-kinase and actin assembly are involved in macrophage invasion by Trypanosoma cruzi. American J ournal of Pathology (in press).

17. Ferreira SR \& De Souza W (1998). Effect of protein kinase inhibitors on the process of Toxoplasma gondii-macrophage interaction. Cell Structure and Function (in press).

18. Meirelles $\mathrm{MN}$, Araujo-j orge $\mathrm{TC} \& \mathrm{De}$ Souza W (1982). Interaction of Trypanosoma cruzi with macrophages in vitro: dissociation of the attachment and internalization phases by low temperature and cytochalasin B. Zeistchrift für Parasitenkunde, 68: 7-14.

19. Ford J W, Welling TH, Stanley JC \& Messina LM (1996). PKH 26 and 125I-
PKH95: characterization and efficacy as labels for in vitro and in vivo endothelial cell localization and tracking. J ournal of Surgical Research, 62: 23-28.

20. Siegle R, Sternson LA \& Stobaugh J F (1989). Suitability of DTAF as a fluorescent labelling for direct analysis of primary and secondary amines - spectral and chemical reactivity considerations. J ournal of Pharmaceutical and Biomedical Analysis, 7: 45-55.

21. Ward GE, Miller LH \& Dvorak J A (1993). The origin of parasitophorous vacuole membrane lipids in malaria infected erythrocytes. J ournal of Cell Science, 106: 237248.

22. Rodman JS, Mercer RW \& Stahl PH (1990). Endocytosis and transcytosis. Current Opinion in Cell Biology, 2: 664-672.

23. Racoosin EL \& Swanson JA (1993). Macropinosome maturation and fusion with tubular lysosomes in macrophages. J ournal of Cell Biology, 121: 1011-1020.

24. Griffin FM, Griffin J A, Leider J E \& Silverstein SC (1975). Studies on the mechanism of phagocytosis. I. Requirement for circumferential attachment of particlebound ligands to specific receptors on the macrophage plasma membrane. J ournal of Experimental Medicine, 142: 12631282.

25. Silva SRL, Meirelles SSL \& De Souza W (1982). Mechanism of entry of Toxoplasma gondii into vertebrate cells. J ournal of Submicroscopic Cytology, 14: 471482.

26. Clemmens DL \& Horwitz MA (1992). Membrane sorting during phagocytosis selective exclusion of major histocompatibility complex molecules but not complement receptor CR3 during conventional and coiling phagocytosis. J ournal of Experimental Medicine, 175: 1317-1326.

27. Hall BF, Furtado GC \& J oiner KA (1991). Characterization of host-cell derived membrane proteins of the vacuole surrounding different intracellular forms of Trypanosoma cruzi in $\mathbf{7 7 4}$ cells. Evidence for phagocyte receptor sorting during early stages 
of parasite entry. J ournal of Immunology, 147: 4313-4321.

28. Meirelles MNL \& De Souza W (1986). The fate of plasma membrane macrophage enzyme markers during endocytosis of Trypanosoma cruzi. J ournal of Submicroscopic Cytology, 17: 327-334.

29. Pimenta PFP \& De Souza W (1988). Freeze fracture and cytochemistry study of the interaction between Leishmania mexicana amazonensis and macrophages. J ournal of Submicroscopic Cytology, 20: 89-99.

30. Russel DG, Xei S \& Chakraborty P (1992). Intracellular trafficking and the parasitophorous vacuole of Leishmania mexicana infected macrophage. J ournal of Cell Science, 103: 1193-1210.

31. De Carvalho L \& De Souza W (1989). Cytochemical localization of plasma membrane enzyme markers during intemalization of tachyzoites of Toxoplasma gondii by macrophages. J ournal of Protozoology, 36: 164-170.

32. Carruthers VB \& Sibley LD (1997). Sequential protein secretion from three distinct organelles of Toxoplasma gondii accompanies invasion of human fibroblasts. European J oumal of Cell Biology, 73: 114123.

33. Ossorio PN, Dubremetz J F \& J oiner KA (1994). A soluble secretory protein in the intracellular parasite Toxoplasma gondii associates with the parasitophorous vacuole membrane through hydrophobic interactions. J ournal of Biological Chemistry, 269: 15350-15357.

34. Sibley LD, Krahenbuhl J L, Adams GM \& Weidner E (1986). Toxoplasma modifies macrophage phagosomes by secretion of a vesicular network rich in surface proteins. J ournal of Cell Biology, 103: 867874.

35. Ashley DM, Bol SJ, Waugh C \& Kannourakis G (1993). A new approach to the measurement of different in vitro leukemia cell growth parameters: the use of PKH GL fluorescent probes. Leukemia Research, 17: 873-882.

36. J oiner KA (1991). Rhoptry lipids and parasitophorous vacuole formation: a slippery issue. Parasitology Today, 7: 226227.

37. Sinai AP \& J oiner KA (1997). Safe haven: the cell biology of nonfusogenic pathogen vacuoles. Annual Review in Microbiology, 51: 415-462.

38. Suss-Toby E, Zimmerberg J \& Ward GE (1996). Toxoplasma invasion: The parasitophorous vacuole is formed from host cell plasma membrane and pinches off via a fusion pore. Proceedings of the National Academy of Sciences, USA, 93: 84138418.

39. Porchet-Hennere E \& Torpier G (1983). Relations entre Toxoplasma et sa cellule hôte. Protistologica, 19: 357-370.

40. De Carvalho L \& De Souza W (1990). Internalization of surface anionic sites and phagosome-lysosome fusion during interaction of Toxoplasma gondii with macrophages. European J ournal of Cell Biology, 51: 211-219.

41. Mikkelsen RB, Kamber M, Wadwa KS, Lin PS \& Schmidt-Ullrich R (1988). The role of lipids in Plasmodium falciparum invasion of erythrocytes: a coordinated biochemical and microscopic analysis. Proceedings of the National Academy of Sciences, USA, 85: 5956-5960.
42. Beckers CJ M, Dubremetz J F, MercereauPuijalan D \& J oiner KA (1994). The Toxoplasma gondii rhoptry protein ROP2 is inserted into the parasitophorous vacuole membrane, surrounding the intracellular parasite, and is exposed to the host cell cytoplasm. J ournal of Cell Biology, 127: 947-961.

43. Sam-Yellowe TY, Shio $H \&$ \& Perkins $M E$ (1988). Secretion of Plasmodium falciparum rhoptry protein into the plasma membrane of host erythrocytes. J oumal of Cell Biology, 106: 1507-1513.

44. Johnson LV, Walsh ML, Bockus BJ \& Chen LB (1981). Monitoring of relative mitochondrion membrane potential in living cells by fluorescence microscopy. J ournal of Cell Biology, 88: 526-535.

45. Melo EJT, Carvalho TU \& De Souza W (1992). Penetration of Toxoplasma gondii into host cells induces changes in the distribution of the mitochondria and the endoplasmic reticulum. Cell Structure and Function, 17: 311-317.

46. Lipsky NG \& Pagano RE (1985). A vital stain for the Golgi apparatus. Science, 228: 745-747.

47. Melo EJ T \& De Souza W (1996). Pathway of C6-NBD-ceramide on the host cell infected with Toxoplasma gondii. Cell Structure and Function, 21: 47-52.

48. Lee $C \&$ Chen LB (1988). Dynamic behavior of endoplasmic reticulum in living cells. Cell, 54: 37-46.

49. Melo EJ T \& De Souza W (1997). Relationship between the host cell endoplasmic reticulum and the parasitophorous vacuole containing Toxoplasma gondii. Cell Structure and Function, 22: 317-323. 